\title{
Obituary
}

The Council have to record with deep regret the deaths of many of its members during the year. Those who lost their lives in the $\mathrm{R} 101$ disaster were recorded in the November Journal.

\section{Harry Bolsover, Associate Member}

Harry Bolsover died as the result of an accident when the City of Washington, in which he was travelling, made a forced landing. $\mathrm{He}$ was elected an Associate Member in ro25 and was not only a very keen member of the Society, but a very active member of the Manchester Branch.

Mr. Bolsover was educated at Old Trafford Technical School, and served with the British Westinghouse until he was appointed in charge of engine work, engine testing and installation with Messrs. A. V. Roe, with whom he remained intil his death. He had a very considerable flying experience, chiefly on test flights of new machines, and was a very able aeronautical engineer. Harry Bolsover was a very likeable man, popular with those who served with him, and with qualities which it will be difficult to find in another man.

\section{Herbert GuY fFISKe, Companion}

Major H. G. ffiske, who died on July $3^{\text {rd, }}$ r930, had been a member of the Society since I925.

Maior ffiske had been connected with Boulton and Paul, of Norwich, since :907, heing manager of their London office. During the War he served in France, first with the Royal Field Artillery and afterwards with the Royal Flying Corps, subsequently in Mesopotamia and Egypt. He retired with the rank of Major and on demobilisation returned to his duties in London. By the death of Major ffiske the Society has lost one of its most esteemed members.

\section{John Henry Ledeboer, Associate Fellow}

John Henry Ledeboer, who died on February 7 th, was born on November $27^{\text {th, }} 1883$; the son of $\mathrm{H}$. A. Ledeboer, of Manchester. He was educated at Tonbridge and Caius College, Cambridge, of which college he was a scholar. He took a first class in the Medieval and Modern Languages Tripos. From his earliest years he took a keen interest in aviation and on coming down from Cambridge he founded and edited "Aeronautics," of which he was editor from 1907 to 1916. In its pages appeared many important technical articles on aviation, and under. Mr. Ledeboer's editorship the paper became an important publication devoted to technical questions.

During the war he rose to be a Major in the R.A.F. and continued to serve intil shortly before his death. He became an Associate Fellow in rgo8, and was the author or co-author of a number of books on aviation, and numerous technical and other contributions to various papers.

Major Ledeboer was widely known and liked. He was a man of great prilliance and by his early death aviation has lost one who had a wide grasp and an enviable knowledge of British aircraft, one who, as far back as Igo6, foresaw that the world of the future was in the air.

\section{Pandia Antonio Ralli, Associate Fellow}

Mr. P. A. Ralli, who died in a nursing home at the early age of $4 \mathrm{I}$, was an Asscciate Fellow of the Society.

$\mathrm{Mr}$ Ralli, who had been ill for some months, was one of the most brilliant scientific men in aviation, and his death will leave a gap which will be difficult to fill. Educated at Lausanne as an electrical engineer, with a wide knowledge 
of mathematics and physics, Mr. Ralli joined the technical staff of the Fairey Aviation Company in 1916.

From the beginning of his work there his outstanding ability was recognised. He carred out original research on the strength and performance of high-speed and high performance aircraft, which proved of the utmost value. He made a speciai study of the problems connected with airscrews, and it was largely due to his work that the Schneider Trophy was won from Italy in 1927 and retained in 1929. For his work on airscrew design he was awarded, in 1928, the Silver Medal of the Society.

All those who worked under Mr. Ralli, who was head of the Technical Department at Messrs. Fairey's, found his advice and experience placed ungrudgirgly at their disposal. Their loss is a loss to aviation as a whole of a man of great personal charm and ability.

\section{Henry O'Neil de Hane Segrave, Associate}

Major Sir Henry Segrave, who was only elected an Associate of the Society in May, was killed on Lake Windermere on $13^{\text {th }}$ June through the capsizing of the motor-boat Miss England II.

Born on 2and September, 1896 , Sir Henry was educated at Eton and Sandhurst. During the War he served in the and Warwickshire Regiment and then in the Royal Flying Corps. After much service he became disabled as the result of a crash and was posted to the War Office in 1917, and in May, 1918, was appointed Technical Secretary to the Minister for Air. He went to Washington with the British Aviation Mission in the same year.

After the War Sir Henry turned his attention to motor-car racing, and first achieved international fame in 1923 by winning the Grand Prix de France. He won miny other important Continental races during the next few years, and achieved several successes at Brooklands. At Daytona Beach, Florida, in 1926, Sir Henry achieved a world record motor-car speed of 203.988 m.p.h., and his last and greatest triumph in road racing was in March, 1929, when he broke the world record at Daytona in the "Golden Arrow" at an average speed of $33^{1.36}$ m.p.h.

Sir Henry then turned his attention to obtaining the water-speed record for Great Britain, in the achievement of which he met his death.

\section{Captain Charles Sutton, Associate Member}

Captain Charles Sutton, who was killed in a flying accident to the seaplane he was piloting at Toronto in September, was born on August $7^{\text {th }}$, 1894. Edurated at. Clacton, he joined $C$. A. Vandervell's and received training in machineshop work and particularly electrical work.

He joined the R.F.C. in 19I6, and took various engine courses, as well as the pilct's course at the Central Flying School. Captain Sutton had a wide experience of various types of aircraft, from the early Maurice Farman's to the latest type of post-war aircraft. After service on the Western Front he was drafted home in command of detached flights against air raiders. After the War he saw service in Iraq, Egypt and the Sudan, until I926 when he went to Canada and took part in air survey exploration work. He had some 2,000 solo flying hours to his credit and an experience of flying under all conditions which has been given to comparatively few. Captain Sutton became an Associate Membe of the Society in 1926, and was keenly interested in its work. An enthusiast in all he did he will be missed by all those who knew him well, and knew how much his heart was in aviation. 